\title{
民有緑地消失の現状と原因の検証に関する研究
}

\section{Study to Verify the State and Causes of the Loss of Private Green}

\author{
山田 和司 ${ }^{*}$ 浦田 啓充 ${ }^{* *}$ \\ Kazushi YAMADA Hiromitu URATA
}

\begin{abstract}
摘要：良好な都市環境を保全する上で民有緑地の中でも既存樹林地の消失が大きな問題となっている。 本調查では民有緑地保全の検討に資するため，全都道府県及び全政令市を調查対象として，実際にど のような理由から既存樹林地が消失してしまっているのか現状を明らかにするための調查を行った。 その結果, 緑地消失の原因として, 相続発生を契機とするもの, 開発や土地有効利用によるもの, 維 持管理が負担の 3 点に整理された。そして開発や土地有効利用を除くその他の原因について，現状に おける対応策の効果への検証を行うとともに，これを踏まえた今後の課題の整理を行った。
\end{abstract}

\section{1. 調查の背景と目的}

良好な都市環境の形成を図るためには，都市公園等の公共施設 の緑化等のみではなく，民有緑地の保全や創出，特に既存樹林地 の保全が大きな課題である。しかし現状においては大都市及びそ の周辺を中心に，相続発生時に納税のために売却されたり，民間 開発により宅地化されるなどの理由により，緑地の消失がとどま らないことが大きな問題となっている。

樹林地減少に関する既存研究として, 全国レベルで東海林ら" が森林減少の状況を示すとともに，減少の顕著な地域での法によ る保全地区等の指定率の低いことを指摘し，地域レベルでは金 子 ${ }^{2)}$ が市街地内の斜面林に着目し，開発により消失した緑地と残 存した緑地の物的，制度的な比較を行い，保全手法のあり方を検 討している。また個々の都市近郊林所有者を対象として青柳ら ${ }^{3)}$ は，管理の状況や収入，環境保全への意識等を調査している。

しかし民有緑地の保全を検討していくには，個々の消失原因等 を踏まえた保全策の検討が有効となるが，個人のプライバシー問 題もありその実態は，明らかにされてこなかった。

そのため本調査研究では, 消失原因の調査可能な緑地として, 緑地保全を目的とした法制度や条例等の指定解除が行われた民有 緑地を対象とし，どのような理由から指定が解除され，地目が何 に変更されたか等の緑地消失の実態を調查・確認するとともに, その主な消失原因に対する現状の対応策の効果への検証之今後の 課題を整理したものである。

\section{2. 調査の方法}

\section{(1) 調查対象}

本研究でいう民有緑地とは，民有の緑地のうち，(1)国の法律及 び都道府県や市町村が制定した条例や要綱等により地域指定がな され，土地形質の改変，樹木の伐採等の行為の規制を伴ったいわ ゆる地域制緑地として指定していたもので，その全体や一部の指 定の解除等がされたもの，(2)緑のマスタープランや緑の基本計画 等の計画段階で, 重要之判断されたたが開発されてしまったもの などの，既存緑地である。

\section{(2) 調査内容}

調査は以下のような二種類の調查用紙を，全都道府県，全政令 市に配布した。調査用紙記入者は市町村の緑地担当部所である。 (i) 緑地保全制度の解除状況等調查
平成 $7 \sim 9$ 年度の 3 年度間のすべての法令制度指定解除緑地を 調查対象とした。調査内容は, 制度名, 解除された原因, 所有者 が個人か法人か, 解除面積, 市街化区域／市街化調整区域等の別, である。

（ii）解除事例の詳細調査

緑地解除の詳細について調査するため，上記で回答のあったも ののうち, 解除の際に所有者と行政の交渉のあったもの等詳細調 查可能な緑地を， 1 市町村 $3 \sim 4$ 件程度，記入担当者に任意に抽 出してもらい, 周辺の地域概要, 解除前後の土地利用状況, 解除 前後の土地評価単価, 解除原因, 解除の詳細の記述等を調査した。

\section{3. 調查の結果}

（1）緑地保全制度の解除状況等調查

調査の結果，19 都道府県より 541 事例の回答が得られた。 (i) 件数之面積

3 年度間で 541 件, 約 $204 \mathrm{ha}$ の民有緑地が解除されている。

(ii) 解除原因

解除原因で最も多かったのは「開発」の 251 件。次に「相続」 に伴う売却や物納等で 85 件, 自己の住宅建設や駐車場設置なよ゙ の「有効利用」が 44 件，「売却」が 27 件，そして指定契約の 「期間満了」が 22 件となった。

(iii）都道府県別集計

埼玉県が 132 件, 千葉県が 113 件, 神奈川県が 94 件, 東京都 が 65 件の合計 404 件となり，いわゆる首都圈域で解除件数の 75 \%を占める。

(iv) 市街化区域等と解除理由

$$
\text { 表一 } 1 \text { 都市計画区域区分と解除原因 }
$$

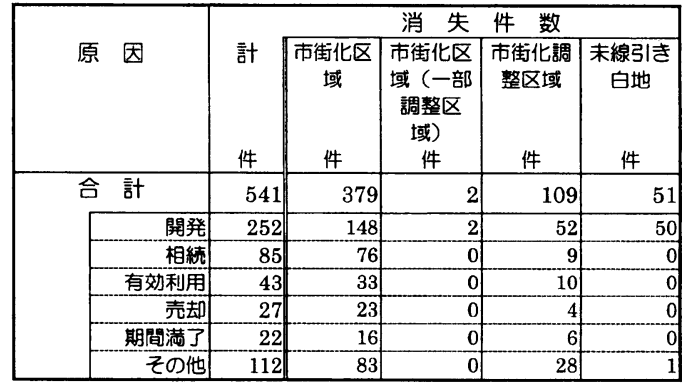

“財団法人日本緑化センター “*国土交通省沖縄総合事務局 
解除全体のうち市街化区域内で 379 件, 市街化調整区域が 109 件となった。「開発」による解除では, 市街化区域が 148 件, 調 整区域と未線引き合わせて 102 件であるが，「相続」による解除 ではほとんどの緑地が市街化区域内となっている（表一1）。

\section{(2) 解除事例の詳細調查の結果}

調查の結果， 200 件の解除事例の回答があった。

(i) 都道府県別集計

埼玉県, 千葉県, 東京都, 神奈川県の 4 都県の回答が 160 件と 全体の 8 割を占めている。

\section{(ii) 緑地の種類}

緑地形態では平地林が 68 件, 斜面林が 66 件となり, 植生では 雑木林が 26 件, 松林が 9 件と多い。

（iii）解除された緑地の面積

1 ha 以下の緑地が 177 件と多く, そのうち $3,000 \mathrm{~m}^{2}$ 以下の屯 のが 127 件となっている。

しかし 2 ha〜 5 ha のものが 6 件, さらに 10ha を超えるような 大規模なものも 5 件みられた。

(iv) 地目の変化

解除後の地目の変化の状況を表一 2 に示す。解除前の地目では 山林が 158 件で最む多い。解除後に山林の半数である 79 件が宅 地となり，31 件は開発予定等があり山林のままである。

\begin{tabular}{|c|c|c|c|c|c|c|c|c|c|c|c|}
\hline \multicolumn{2}{|c|}{ 解除前地目 } & \multicolumn{10}{|c|}{ 解除後の地目等 } \\
\hline 地目前 & 件数 & 宅地 & $\begin{array}{l}\text { 山林 } \\
\text { 宅地 }\end{array}$ & 山林 & \begin{tabular}{|l|} 
雑種 \\
地 \\
\end{tabular} & \begin{tabular}{|l|} 
介在 \\
山林
\end{tabular} & \begin{tabular}{|l|} 
学校 \\
用地 \\
\end{tabular} & \begin{tabular}{|l|} 
境内 \\
地等 \\
\end{tabular} & 原野 & 畑 & 不明 \\
\hline 山林 & 158 & 79 & 3 & 31 & 9 & & 1 & 2 & & 2 & 31 \\
\hline 宅地 & 20 & 19 & & & & & & & & & 1 \\
\hline 雑種地 & 5 & 2 & & & 3 & & & & & & \\
\hline 畑 & 4 & 3 & & & 1 & & & & & & \\
\hline 原野 & 3 & 2 & & & & & & & 1 & & \\
\hline 介在山林 & 2 & 1 & & & & 1 & & & & & \\
\hline 学校用地 & 1 & & & & & & 1 & & & & \\
\hline 境内地 & 1 & & & & & & & 1 & & & \\
\hline 公園 & 1 & & & & & & & & & & 1 \\
\hline 不明 & 5 & & & & & & & & & & 5 \\
\hline 計 & 200 & 106 & 3 & 31 & 13 & 1 & 2 & 3 & 1 & 2 & 38 \\
\hline
\end{tabular}

(v) 市街化区域等

市街化区域内の緑地が 150 件，市街化調整区域は 42 件であっ た。

\section{（vi）用途地域の種類}

緑地が存在した場所の用途地域は, 住居地域に位置したものが 137 件で最も多い。

(vii) 利用状況

解除前の緑地は, 積極的利用がされていなかったものが 166 件 で最も多かった。緑地解除後の土地利用は, 戸建や集合住宅となっ たものが 117 件, 店舗や事務所等になったものが 17 件, 駐車場 が 14 件，未利用のままのものが 10 件等となっている。

（viii）解除原因（重複回答）

民間開発事業としたものが 64 件で最も多く，ついで所有者に よる住宅や駐車場の建設といった土地の有効利用が 59 件, 相続 税納税のためが 37 件, 維持管理ができないためが 27 件の順となっ た。

\section{（3）解除原因の詳細}

重複回答から得られた解除原因を表一 3 に示す。「開発」単独 が 64 件中 44 件, 「土地の有効利用」単独は 59 件中 40 件之, 背 景に相続対策等の理由が無く, 純粋に開発目的で解除されてしま うものが多いことが分かった。緑地を「維持管理ができないため」 としたものでは, 27 件の内 14 件が単独原因となり, 所有者が緑 地の維持管理を負担に感じていることを表している。「相続税納
表一 3 解除原因（重複回答）

\begin{tabular}{|c|c|}
\hline 衰失原因 & 件数 \\
\hline 民間開発事業 & 64 \\
\hline 土地の有効利用 & 59 \\
\hline 相続税納税のため & 37 \\
\hline 維持管理ができないため & 27 \\
\hline 相続の事前対策 & 14 \\
\hline 固定資産税、都市計画税が負担なため & 5 \\
\hline 公共事業 & 4 \\
\hline その他 & 27 \\
\hline
\end{tabular}

税のため」では, 単独回答が 37 件中 33 件と, 相続が解除の直接 的原因となりやすい。「相続の事前対策」は，「土地の有効利用」 との重複が 14 件中 6 件,「開発」との重複も5 件と, 相続の事前 対策としての開発目的で解除されていることが読み取れる。 他の調查項目と合わせ，それぞれの解除原因の特徴を示す。 （i ）民間開発事業 + 土地の有効利用（113 件）

このタイプの事例においては，指定解除前から所有者が住宅等 の建設予定を持っており, それを行うため解除の申請が行われ， 消失したものが多い。解除後の形態で多いものは，住宅建設が 67 件, 次に駐車場が 10 件となっている。

(ii) 相続税納税 + 相続事前対策 (51 件)

相続税納税に伴う売却等による所有権移転は, 38 件となって いる。そのうち自治体への買取り請求を含め 14 件で買取りを検 討したが高額なため 13 件が買取れなかった。また，相続税納税 に伴い，土地の物納が行われたのは 6 件である。

（iii）維持管理できない+税が負担 (28 件)

維持管理作業ができないとしたものが 27 件, さらにその内の 4 件では固定資産税・都市計画税む負担であるとしている。固定 資産税・都市計画税負担が解除の直接的原因としたものは 1 件で ある。維持管理作業が困難の具体的理由としては，所有者の高齢 化や健康上の問題を理由とするものが 6 件, 風や松枯れ病による 樹木の倒木や枯死による緑地自体の荒廃が 5 件であった。それ以 外では, 日照問題，緑地へのゴミの不法投裹に対する周辺住民の 苦情による解除が 8 件となっている。

\section{4. 対応策の検討と詳細調查の検証}

民有緑地保全の問題点として, 表一 3 の解除原因から所有者の 発意による開発や土地の有効利用之, 公共事業を除くと, (1)相続 発生によるむの, (2)緑地の維持管理が負担のため, (3)固定資産税 や都市計画税が負担なため，の 3 点に整理される。ここでは相続 発生への対応策の検討と, 緑地維持の負担や固定資産税・都市計 画税の負担がどのように緑地解除の原因となるのか検証を行う。

\section{（1）相続税を契機とした緑地解除への対応}

地方自治体の緑地保全担当者から，相続税を契機とした緑地消 失が問題だとよく言われており，本調査からも相続発生が緑地消 失の原因となることが認められた。そこで法的制度指定緑地に対 する相続税の特例措置（相続税減免・納税猶予）を講じた場合の

\section{表 -4 相続試算条件}

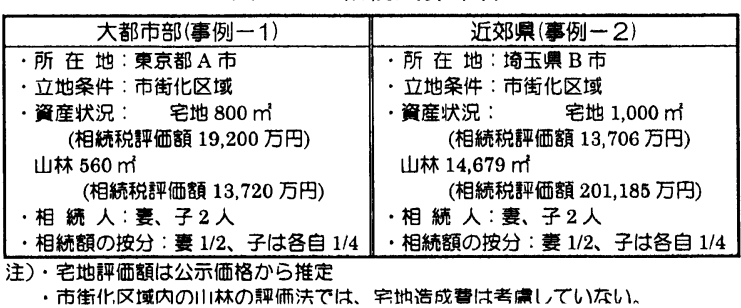


相続税額を試算し，相続税納税に対し相続税の特例措置がどのよ うな効果があるのか検討した。

(i) 試算の地域設定

大都市部（都心より $17 \mathrm{~km}$ ) における小規模な緑地消失 $\left(560 \mathrm{~m}^{2}\right)$ 之, 近郊県（都心より $30 \mathrm{~km}$ ）における比較的大規模な緑地消失 （1.5ha）を設定した。設定面積は解除事例を基としているが, 統計デー夕（農業経営動向統計 平成 9 年度, 農林水産省統計情 報部）であ南関東の農家あたりの山林所有平均面積は $0.48 \mathrm{ha}$, 全国平均は $1.46 \mathrm{ha}$ となり, 地域により所有地全体に占める山林 の割合が大きく異なっている。宅地については該当地域の平均的 な農家宅地面積をヒアリングした。

（ii）試算の条件と内容

試算では表一 4 のように条件設定し，2 割から納税猶予までの 相続税評価減の減免効果を検討した。主な現行制度として都市緑 地保全法による市民緑地は 2 割, 緑地保全地区は 4 割, 保安林は $2 \sim 8$ 割, 生産緑地は納税猶予の減免がされている。結果を事例一 1 は表- 5 に，事例- 2 を表- 6 に示す。

\section{表 -5 大都市部の小規模緑地消失事例（事例 - 1 ）}

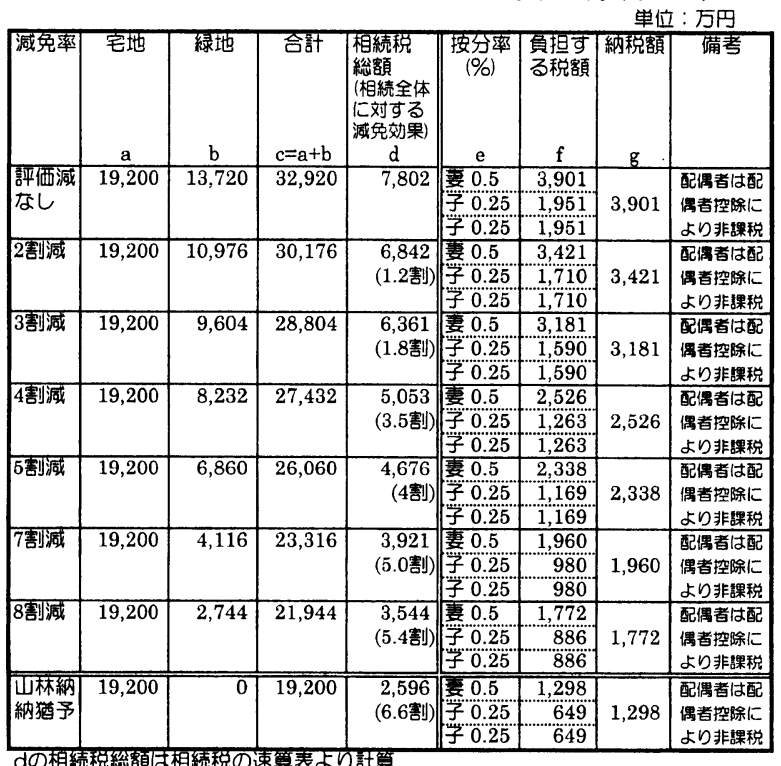

表 - 6 近郊県の大規模緑地消失事例（事例 - 2)

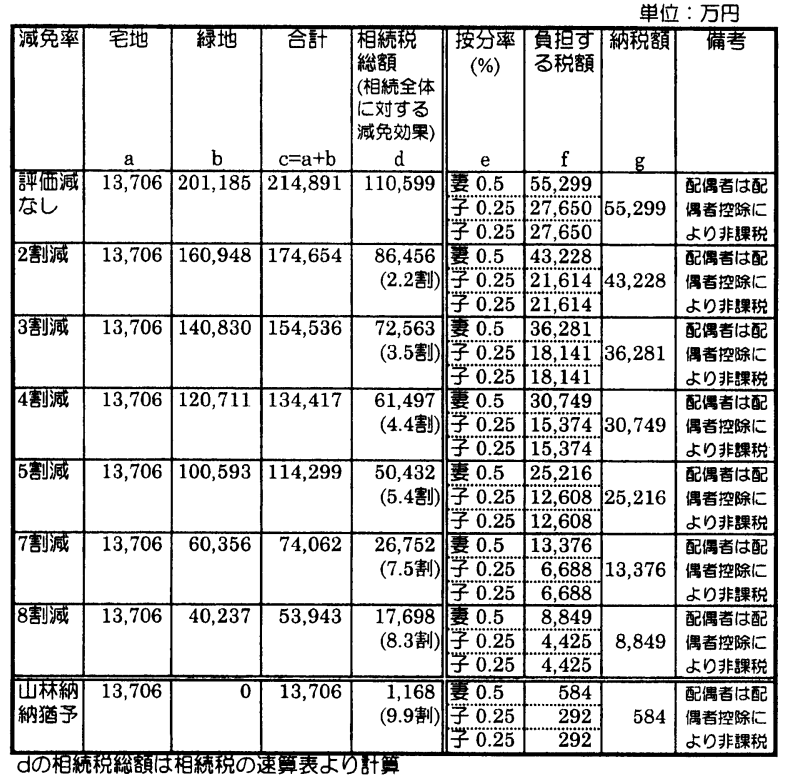

表 -7 相続税の特例の効果

\begin{tabular}{|c|l|l|c|c|}
\hline 事例 & \multicolumn{1}{|c|}{ 地域 } & 所有者の特徵 & $\begin{array}{c}\text { 相続全体に } \\
\text { 占める緑地 } \\
\text { の割合 }\end{array}$ & $\begin{array}{c}\text { 相続税の特 } \\
\text { 例の効果 }\end{array}$ \\
\hline 事例-1 & 大都市部 & $\begin{array}{l}\text { 小規模な緑地 } \\
\text { を所有 }\end{array}$ & 小 & 低 \\
\hline 事例-2 & 近郊県 & $\begin{array}{l}\text { 規模の大きな } \\
\text { 緑地を所有 }\end{array}$ & 大 & 高 \\
\hline
\end{tabular}

(iii) 試算結果

2 事例の計算結果からは, 相続の全体に占める緑地の評価額の 割合が高い場合, 減免の効果は高い事が想定される。事例 - 1 (表一 5 ) のような相続税総額に占める緑地評価額の割合が低い 大都市部では, 相続税全体への緑地の減免効果は低い。しかし事 例一-2（表-6）のように近郊県で大規模な緑地を有し相続税総 額に占める緑地の割合が大きな場合の隇免効果は高く, 緑地消失 の対伈策として相続税特例措置（相続税減免，納税猶予）は，大 都市部に比べ有効な手法であると考えられる（表一7）。

しかし, 事例一 1 では緑地の納税猶予措置を講じた場合でも, 宅地のみに課せられる相続税により納付する税額は子 2 人で 1,300 万円となり（妻は配偶者控除により非課税），奏際の相続 ではこれに家屋等も課税対象に加わるため税額は增加することが 予想される。統計デー夕 ${ }^{4}$ より平成 10 年度の 1 世帯当たり平均 眝蓄保有額が 1,309 万円であることを考慮すると，貯蓄のみによ る相続税納税が困難である状況がうかがえる。事例 -2 について も納税猶予措置を講じた場合でも子 2 人で 584 万円額の相続税納 税が必要となる。

このように法的制度指定による相続例特例措置は，緑地の大小 により効果の高い, 低いはあるものの有効な手法の一つであるこ とは確認されたが，相続問題全体からみると，相続人が相続税を 納税するために, 宅地や農地に比べ手放しやすい緑地が売却され てしまうという図式は残るものと考えられる。

\section{（2）緑地の維持管理が負担で解除された事例}

\section{(i) 解除された緑地の面積}

維持管理が大変とされた緑地の面積は，2,000 $\mathrm{m}^{2}$ 以下が 27 件中 16 件でさらにその内 $1,000 \mathrm{~m}^{2}$ 以下は 7 件之, 大規模なものばかり でなく，比較的小規模な緑地でも維持管理が負担となっている。 (ii）周辺の土地利用状況

10 件で周辺住民の苦情が解除の大きな要因となっている。そ れらは落葉や日照問題, そして緑地へのゴミの不法投棄などであっ た。これら 10 件中 6 件において調查時に添付された地図から, 周辺状況を調べた結果， 2 万向で住宅に隣接したものが 1 件， 3 方向が 3 件， 4 方向が 1 件であった。このように，市街地に位置 し住宅に隣接した緑地の維持管理への苦情が多いことが読み取れ る。このことは, 特に市街地内においては, 自然的緑地であって も適切な管理の必要性が求められている。

(iii) 解除された緑地に対する管理助成等

8 件で緑地の管理費相当の助成金のみとなっている。その他で は 9 件で固定資産税・都市計画税の減免や税相当の助成とともに,

\section{表-8 「税が負担」と回答された緑地にかかる固定資産税等}

\begin{tabular}{|c|c|c|c|c|c|c|c|}
\hline \multirow{2}{*}{$\begin{array}{l}\text { 事 } \\
\text { 例 }\end{array}$} & \multirow{2}{*}{$\begin{array}{l}\text { 緑地 } \\
\text { 面積 } \\
\left(\mathrm{m}^{\prime}\right)\end{array}$} & \multicolumn{3}{|c|}{ 緑地に対する税合計 } & \multirow{2}{*}{$\begin{array}{l}\text { 助成の } \\
\text { タイプ }\end{array}$} & \multirow[b]{2}{*}{$\begin{array}{c}\text { 緑地に } \\
\text { 対する } \\
\text { 助成額 } \\
\text { (円) }\end{array}$} & \multirow[t]{2}{*}{ 僃考 } \\
\hline & & $\begin{array}{c}\text { 固定咨 } \\
\text { 形税 a } \\
\text { (円) }\end{array}$ & $\begin{array}{c}\text { 都市計 } \\
\text { 画税 b } \\
\text { (円) }\end{array}$ & $\begin{array}{c}c=a+b \\
\text { (円) }\end{array}$ & & & \\
\hline 1 & 2,970 & 510 万円 & 110 万円 & 620 万円 & 助成 & 1 万円 & $\begin{array}{l}\text { 保存樹 } 86 \text { 本。 } \\
\text { 助成上限の1万 } \\
\text { 円 }\end{array}$ \\
\hline 2 & 458 & 156万円 & 34 万円 & 190 万円 & 助成 & 9干円 & 年額 $20 \mathrm{H} / \mathrm{m}^{2}$ \\
\hline 3 & 7,105 & 1690 万円 & 362 万円 & $2052 万 \mathrm{H}$ & 助成 & $145 円$ & 年額 $20 \mathrm{M} / \mathrm{m}^{2}$ \\
\hline 4 & 3,500 & 294万円 & 63 万円 & 357 万円 & - & - & \\
\hline
\end{tabular}

固定资産税、都市計画税は緑地面積と䨤失前証価額をもとに試算 
緑地の管理費相当の助成金も支給されていたが解除されてしまつ ている。

\section{（3）税が負担で解除された事例}

税が負担で解除された事例を表一 8 に示す。固定資産税・都市 計画税が負担としたものでは, 自治体からの「助成」が当該土地 にかかる固定資産税等に対し，まったく小額であることが表より 分かる。このように緑地の規模が大きい場合, 固定資産税・都市 計画税に対する助成がない場合, 所有者の毎年の負担はかなりな あのといえる。

\section{5，民有緑地保全の方向性と課題}

\section{（1）相続税発生への対応}

相続税評価額減免の効果は, 大都市近郊県のように相続全体に 占める緑地の相続税評価額が高い場合はその効果は大きく, 地域 性によって効果が違うことが分かった。民有緑地の公益性の担保 を図るための, 税制措置の一つとして, 相続税特例措置を伴う制 度の制定や減免率の検討は, 地域性を踏まえた場合に緑地保全の 一助につながると考えられる。

しかし, 緑地保全地区（4 割評価減）等, 既存の制度で屯減免措 置がとられている制度があり, その積極的な活用が今後の課題で ある。特に, 大都市部以外においては, 2〜4割の評洒減でも相 続全体での減免効果は大きいことから, どのような制度が相続税 に対してどのような減免措置をむっているかを広報することが大 切である。現行の制度と相続税の評価減を表一 9 に示す。

\section{表 -9 相続評価減と現行制度}

\begin{tabular}{|c|c|c|}
\hline 内容 & 減免率 & 主な現行制度 \\
\hline \multirow[t]{6}{*}{ 評価減 } & 2 割評価減 & 市民緑地 \\
\hline & 3 割評価減 & 保安林(一部皆伐) \\
\hline & 4 割評価減 & $\begin{array}{l}\text { 緑地保全地区、都 } \\
\text { 市公園(借地) }\end{array}$ \\
\hline & 5 割評価減 & 保安林(卓报) \\
\hline & 7 割評価減 & 保安林(单木選报) \\
\hline & 8 割評価減 & 保安林 (禁伐) \\
\hline 納税猶予 & 納税猶予 & 生産緑地 \\
\hline
\end{tabular}

また，消失原因の中で相続発生時には，所有者より公共団体に 対し買取請求がなされる場合が多いことが分かった。それらに対 して, 多くの場合が予算の不足から買取が行えず, 緑地が消失し
ている結果となっている。いずれにしてあ相続全体の中で宅地や 農地に比べ緑地が売却される可能性は, 税の特例措置が適応され た後む残ると考えられる。このような事実から，緑地の買取シス テムの充実により買取請求に対する適切な対応が求められる。 特に, 相続税の減免効果の低い大都市周辺部においては, 重要な 緑地の把握や買取のための予算措置等のシステムの整備が急務で ある。

\section{（2）地方税（固定資産税，都市計画税）の負担への対応}

大都市の場合, 固定資産税及び都市計画税も表一 8 にみられる ように大きな金額となる。地方税の場合, その対応はある程度地 方自治体に委秝られていることから,市民等に緑地の重要性・必 要性を十分広報の上, 税相当額を助成するか, 非課税及び評価減 の処置を行い緑地所有者の負担を軽くすることが望まれる。

この場重要となるのが公共性の実証である。例えば，期間を限 定してあ公開されている緑地であれば，公園的機能の代償として 市民に理解されやすい。また対象緑地に貴重な植物や生き物が生 息している場合など，地域資産の保護的な観点から公共的対応へ の理解が得られやすい。これらのことに市民コンセンサスを得る ための要綱等の整備が望まれる。

\section{（3）緑地維持への対応}

一般に樹林地は，何もせず自然のまま放置することが自然保護 上は望ましいとする観点がある。しかし，都市域に存在する樹林 地の多くが, 二次植生であり, 過去に何らかの人為的管理が入っ ていた緑地である。このような緑地が自然放置されると，見た目 には緑地というよりも荒地であり，管理されていない土地として ゴミの不法投機等の被害を受ける結果となる。このことは, まず 都市域に存在する樹林地は, 緑地としての健全性や生態的な基本 構造を維持するためにはある一定の人為的管理作業が必要である ということのコンセンサスと，緑地所有者にその管理を課すこと の是非を十分に議論することが大切である。

また,「維持管理が困難」の原因として, 所有者の高齢化や健 康上の問題による管理作業の困難, 台風や病中害による樹林の被 害がある。このことは，これらの緑地の管理にあたっては，単に 管理費相当の助成を行い所有者の義務とするのみでなく，所有者 の希望が有れば助成金ではなく自治体等による管理や所有者と協 議の上, 市民参加や環境学習等の一環として周辺住民が係われる ような仕組みなど柔軟な制度としていくことが大切である。

「維持管理が困難」のもうひとつの要因として周辺住民の苦情 がある。地域制緑地の必要性と役割や保全のための手続等につい て，市民全体に認識してもらうため，パンフレット等を作成する など十分な広報活動が重要である。

\section{引用・参考文献}

1 ) 東海林克彦・橋本善太郎・笹岡達男・ 鳥居敏男 (1994)：森林保全の実態之 制度に関する研究：造園雑誌 57(5), 391-396
$2 ）$ 金子忠一(1989): 市街地斜面緑地の 保全に関する研究：造園雑誌 52(5), 294-299

3 ) 青柳みどり・山根正伸（1991）: 都市 近郊林保全のための林地所有者の行動
についての実証的研究：造園雑誌 $54(4), 266-272$

4 ）眝蓄広報中央委員会（1998）: 貯蓄之 消費に関する世論調査 平成 10 年度, $187 \mathrm{pp}$

Summary: The loss of private green has become a great problem to the preservation of comfortable environment in urban areas. This study is making for examination for preservation of private green. It confirmed the present situation by ascertaining the actual reasons for the loss of private green. And, it covers autonomous cities and all prefectures. The causes of green loss was pigeonholed to three categories, loss arising from the inheritance of land, loss as a result of development or more effective land use, and loss as a result of a heavy burden of administering and maintaining of land. At the same time, at these three causes except loss as a result of development or more effective land use, through the use of simulations, it verified the effectiveness of a special measure concerning the inheritance tax as a means of preserving green. And it has verified, the reasons why a heavy burden of administering and maintaining of land is related to the loss of private green. 